\title{
GRANICE INGERENCJI W INTYMNOŚĆ CZLOWIEKA. CZĘŚĆ I
}

Streszczenie. W artykule poruszono wybrane problemy związane z kryminalizacją takich zachowań jak: prostytucja, kazirodztwo, wykorzystanie seksualne dzieci. Zajęto się także ochroną pokrzywdzonych w postępowaniu karnym poprzez ograniczenia jawności.

Słowa kluczowe: populizm penalny, przestępstwa seksualne, prostytucja, kazirodztwo, wykorzystanie seksualne dzieci, wtórna wiktymizacja.

Prawna regulacja sfery intymnej ludzi, zwłaszcza w dziedzinie prawa karnego, wymaga bardzo poważnego rozważenia potrzeby i granic kryminalizacji zachowań z tej sfery. Odnosi się to szczególnie do przestępstw o charakterze seksualnym.

Truizmem byłoby stwierdzenie, że prawo karne kryminalizuje niektóre zachowania o charakterze dewiacyjnym, przy czym nie każda dewiacja winna być opatrzona sankcją prawnokarną i nie wszystkie zakazy prawnokarne mają swoje odbicie w normach społecznych. Wiara w to, że normy prawne są szybko internalizowane przez społeczeństwo, a prawo, w tym nade wszystko karne, może łatwo kształtować postawy, stanowi wyraz myślenia życzeniowego. Ponadto normy społeczne i normy prawa karnego w zakresie seksualności nie są tożsame dla całej ludzkości ani niezmienne w czasie. Dlatego też, zwłaszcza w tej dziedzinie, warto spojrzeć na prawo nie tylko na płaszczyźnie dogmatycznej, ale trzeba wejść w sferę aksjologiczną. Tak jak nie kwestionuje się samej kryminalizacji zgwałcenia, czy też zachowań seksualnych z osobami poniżej lat 15 , to należy postawić pytania zarówno o zmianę trybu ścigania zgwałcenia, rozważając sposób reakcji w sytuacjach granicznych, jak i o zasadność kryminalizacji kazirodztwa czy praktyk BDSM.

Do takiej problematyki nawiązuje zeszyt 85. czasopisma Acta Universitatis Lodziensis. Folia Iuridica. Otwiera go artykuł Klaudii Gaczoł odnoszący się do kwestii populizmu penalnego. Podejmowanie decyzji kryminalizacyjnych i dekryminalizacyjnych powinno być nacechowane racjonalnością, a ustawodawca nie może kierować się głównie aktualnymi odczuciami społecznymi. Pamiętać trzeba przede wszystkim o zasadach teorii kryminalizacji, tzn. że najpierw należy

* Uniwersytet Łódzki, Wydział Prawa i Administracji, Katedra Postępowania Karnego i Kryminalistyki, zbigniew.wardak@gmail.com. 
stwierdzić w rzeczywistości społecznej zachowania odbierane przez społeczeństwo jako niebezpieczne, a potem rozważyć konieczność reakcji prawnokarnej. Niezbędna jest ocena przydatności zastosowania normy prawnokarnej oraz proporcjonalności reakcji prawnokarnej, a wreszcie możliwość ujęcia zakazu w sposób uwzględniający zasady prawa karnego (Kulesza 2014, 87). Nieposzanowanie tych zasad prowadzi częstokroć do populizmu karnego, owocującego tworzeniem norm prawnokarnych, które np. nie są zinternalizowane społecznie, są niemożliwe do zastosowania lub wywołują niepożądane społecznie skutki. Niestety trzeba się zgodzić z Klaudią Gaczoł, że aktualnie penalnopopulistyczna retoryka bierze górę nad racjonalną filozofią karną, a wiara w omnipotencję karnego instrumentarium, w tym w moc kary pozbawienia wolności, wydaje się złudna (Gaczoł 2018, 21)1.

W problematyce związanej z seksualnością istotne jest zagadnienie prostytucji. Dotychczasowe doświadczenia prowadzą do wniosku, iż prostytucji nie można zlikwidować, natomiast dyskusyjne jest, czy należałoby ją zalegalizować, które to rozwiązanie, jak słusznie zauważa Marlena Drapalska-Grochowicz, z jednej strony sprzyjałoby bezpieczeństwu usług seksualnych, zwiększyłoby skuteczność walki z handlem żywym towarem, a osoby świadczące usługi seksualne zyskałyby prawa pracownicze, z drugiej strony przyczyniłoby się do większego uprzedmiotowienia kobiet. Legalizacja byłaby sygnałem, że człowiek jest jak towar wielokrotnego użycia, a prostytucja to nieszkodliwa zabawa (Drapalska-Grochowicz 2018, 43). Słuszna jest także konstatacja Pauliny Szoty, że karalne jest tylko sutenerstwo, stręczycielstwo, kuplerstwo i zmuszanie do prostytucji, jakby ustawodawca nie dostrzegał innych aspektów związanych z tym zjawiskiem, a aktualne regulacje prawne nie są wystarczające, aby zapobiec jego rozwojowi (Szota 2018, 58).

Innym problemem jest kazirodztwo, którego penalizacja wywołuje dyskusję. Jan Okoński zauważył, że przepis art. 201 k.k. przewiduje normę sankcjonującą również w przypadku stosunków pomiędzy niespokrewnionymi biologicznie dorosłymi ludźmi, np. przysposobionym i przysposabiającym, odbywających się za ich wspólną zgodą. Można to potraktować jako naruszenie wolności seksualnej człowieka (Okoński 2018, 68). Autor zaznaczył, że dobrem chronionym przez art. 201 k.k. jest obyczajność, co oczywiście znajduje odzwierciedlenie w rodzajowym przedmiocie ochrony, jednakże w doktrynie wskazuje się na różne przedmioty ochrony: interes populacyjny, rodzinną strukturę społeczeństwa, a także na to, że kazirodztwo stanowi szczególny typ nadużycia stosunków zależności (Krajewski 2016, 8-10). W przypadku stosunku pomiędzy dorosłym przysposabiającym a przyspasabianym może dochodzić np. do wychowywania przyszłego partnera seksualnego, stąd też wydaje się, że kwestia dobrowolności

${ }^{1}$ Pokutuje tu zdaje się myśl podobna do teorii przymusu psychicznego Anselma von Feuerbacha, która wprawdzie na początku wieku XIX była nowatorska, to jednak, w toku późniejszych dokonań nauki i doświadczeń, nie do końca należy uznać ją za podstawę dla działań racjonalnego ustawodawcy, którego przedstawiciele często nawet o tym myślicielu nie słyszeli. 
późniejszych kontaktów seksualnych nie jest wystarczającym argumentem za ich depenalizacją ${ }^{2}$. Maciej Para natomiast podał kazirodztwo jako przykład victimless crime, stwierdzając, że kryminalizowanie stosunków kazirodczych wydaje się bezcelowe, jeśli bowiem cokolwiek ulega naruszeniu w sytuacji dobrowolnego stosunku kazirodczego między dorosłymi, to mogą być to, co najwyżej, przekonania światopoglądowe poszczególnych jednostek (Para 2018, 75), co również jest uproszczeniem perspektywy. Przestępstwa bez ofiar można ujmować jako kategorię merytoryczną i kategorię techniczną: pierwsze ujęcie odnosi się do czynów niebędących społecznie niebezpiecznych w stopniu niezbędnym do uznania ich za przestępstwa, ale uznanych za przestępstwa ze względu na tradycję; drugie ujęcie ma zastosowanie w przypadku braku określonego pokrzywdzonego doznającego szkody i mogącego zawiadomić o popełnieniu przestępstwa (Falandysz 1976, 53-54). Sam brak zainteresowanego pokrzywdzonego nie jest warunkiem wystarczającym do podjęcia decyzji dekryminalizacyjnej, co nie oznacza, że nie należy dyskutować o potrzebie i zakresie penalizacji kazirodztwa.

$\mathrm{Z}$ innego rodzaju problemami spotykamy się w odniesieniu do zachowań $z$ art. 200 k.k, choć sama ich kryminalizacja zasadniczo nie jest dyskusyjna. Diana Szwejser zwraca uwagę na niektóre sytuacje, jak ta, gdy dochodzi do kontaktów seksualnych między dwiema osobami małoletnimi, kiedy jedna z tych osób nie jest już nieletnia (ukończyła 17 lat), zaś druga nie ukończyła jeszcze 15. roku życia. Różnica wieku jest tutaj bardzo niewielka, a jeszcze mniejsza może być różnica $\mathrm{w}$ dojrzałości emocjonalnej, co nakazuje się zastanowić nad sposobem reakcji w podobnych przypadkach. Autorka wysunęła słuszny postulat de lege ferenda poprzez dodanie w art. 200 k.k. typu uprzywilejowanego w sytuacji, kiedy pomiędzy sprawcą a ofiarą występuje niewielka różnica wieku, czy też umożliwienie sądowi wydania wówczas wyroku warunkowo umarzającego, odstąpienie od wymierzenia kary, a skupienie się na poprawie postawy społecznej takiego oskarżonego (Szwejser 2018, 88).

W związku z przyjęciem zawiadomienia i przesłuchaniem pokrzywdzonych przestępstwami z art. 197-199 k.k. w trybie art. 185c k.p.k. zasadniczo podzielić należy pogląd Sławomira Tkacza, że w regulacjach tych słusznie stosuje się szczególny tryb, aby ograniczyć wtórną wiktymizację (Tkacz 2018, 95). W tymże trybie najpierw składa się zawiadomienie o przestępstwie, które w przypadku składania go przez pokrzywdzonego powinno zostać ograniczone do najważniejszych faktów i dowodów, a później dochodzi do przesłuchania przez sąd.

Niekiedy ofiary chcą od razu przekazać całość znanych okoliczności, „wyrzucić je z siebie", a odkładanie tego może, wbrew słusznej woli ustawodawcy, doprowadzić do wtórnej wiktymizacji. Wątpliwości z punktu widzenia

${ }^{2}$ Należałoby się natomiast zastanowić nad zasadnością kryminalizacji stosunków seksualnych pomiędzy rodzeństwem niespokrewnionym biologicznie, powstałym wskutek wzajemnego przysposobienia przez rodziców. 
pokrzywdzonych budzi także zmiana trybu ścigania w przestępstwie zgwałcenia, kiedy ofiara może nie chcieć składać zawiadomienia o popełnieniu tego przestępstwa, a wskutek złożenia zawiadomienia przez inną osobę jest zmuszona zeznawać, co również może powodować wtórną wiktymizację. Paulina Konca zwraca uwagę, że wyłączenie jawności w sprawach o przestępstwa seksualne jest powszechne (Konca 2018, 105), przy czym nie jest tu wyłączną przesłanką ważny interes prywatny (art. $360 \S 1$ pkt 1 lit. d k.p.k.), w grę bowiem wchodzi również obraza dobrych obyczajów (art. $360 \S 1$ pkt 1 lit. b k.p.k.), a prawa pokrzywdzonych chronią w niektórych sytuacjach także przesłuchania w trybach $\mathrm{z}$ art. 185a-185c k.p.k., w ramach których wdrożono dyrektywę Parlamentu Europejskiego i Rady 2012/29/UE z dnia 25 października 2012 r., ustanawiającą normy minimalne w zakresie praw, wsparcia i ochrony ofiar przestępstw. Słuszne przy tym są uwagi dotyczące zadawania pytań, jest to jednak sfera wymykająca się regulacji ustawowej, a dokonywanie przesłuchań w taki sposób, aby ograniczyć wtórną wiktymizację, powinno być przedmiotem aplikacji i szkoleń.

Problematyka styku kwestii intymnych z kryminalizacją poszczególnych przestępstw, a także postępowaniem w tych sprawach, jest bardzo obszerna i złożona, a zagadnienia są bardzo dyskusyjne. Nie ma prostych rozwiązań, a wiara w moc przepisów prawa oraz surowych wyroków jest złudna. Dlatego też nie pozostaje nic innego, jak nieustająco postulować, ażeby działania prawodawcy były oparte na dotychczasowych doświadczeniach oraz wskazaniach nauki, nie zaś dążeniu do uzyskania popularności.

\section{BIBLIOGRAFIA}

Drapalska-Grochowicz, Marlena. 2018. „Zjawisko prostytucji - pomiędzy koniecznością a tabu?”. Acta Universitatis Lodziensis. Folia Iuridica 85: 33-45.

Falandysz, Lech. 1976. Wiktymologia. Warszawa: Wiedza Powszechna.

Gaczoł, Klaudia. 2018. „Między naukowością a populizmem penalnym. Kilka uwag o socjalizacji prawnej w kontekście polskich regulacji przestępstw seksualnych". Acta Universitatis Lodziensis. Folia Iuridica 85: 11-32.

Konca, Paulina. 2018. „Jawność postępowania karnego a prywatność jego uczestników w sprawach o przestępstwa na tle seksualnym. Aspekt prawnoporównawczy". Acta Universitatis Lodziensis. Folia Iuridica 85: 101-118.

Krajewski, Radosław. 2016. „Uzasadnienia kryminalizacji kazirodztwa”. Prokuratura i Prawo 6: $5-28$.

Kulesza, Jan. 2014. „Zarys teorii kryminalizacji”. Prokuratura i Prawo 11-12: 87-111.

Okoński, Jan. 2018. „Kazirodztwo jako przykład sporu między prawem naturalnym a pozytywnym”. Acta Universitatis Lodziensis. Folia Iuridica 85: 63-70.

Para, Maciej. 2018. „Bezzasadność karania stosunków kazirodczych a kwestia potomstwa”. Acta Universitatis Lodziensis. Folia Iuridica 85: 71-80.

Szota, Paulina. 2018. „Prostytucja i jej nowe formy oraz zjawiska pokrewne a regulacje prawne”. Acta Universitatis Lodziensis. Folia Iuridica 85: 47-61. 
Szwejser, Diana. 2018. „Granica ingerencji w sferę intymną osób poniżej 15. roku życia. Zgoda nieletniego poniżej 15. roku życia na obcowanie płciowe a sankcja z art. $200 \S 1$ kodeksu karnego". Acta Universitatis Lodziensis. Folia Iuridica 85: 81-89.

Tkacz, Sławomir. 2018. „O przesłuchaniu pokrzywdzonych przestępstwami z art. 197-199 k.k. Studium z zakresu stosowania prawa”. Acta Universitatis Lodziensis. Folia Iuridica 85: 91-100.

\title{
Akty prawne
}

Dyrektywa Parlamentu Europejskiego i Rady 2012/29/UE z dnia 25 października 2012 r. ustanawiająca normy minimalne w zakresie praw, wsparcia i ochrony ofiar przestępstw oraz zastępująca decyzję ramową Rady 2001/220/WSiSW (Dz.U. UE L z 2012 r. Nr 315, s. 57).

Ustawa z dnia 6 czerwca 1997 r. - Kodeks karny (tekst jedn. Dz.U. z 2018 r., poz. 1600 ze zm.).

Ustawa z dnia 6 czerwca 1997 r. - Kodeks postępowania karnego (tekst jedn. Dz.U. z 2018 r., poz. 1987).

\section{Zbigniew Wardak}

\section{LIMITS OF INTERFERENCE WITH THE INTIMACY OF THE MAN. PART I}

\begin{abstract}
In the article, there were discussed selected problems associated with the criminalization of such behaviours as: prostitution, incest, child sexual abuse. The article also dealt with protection of aggrieved parties in criminal proceedings through restrictions as for the openness.

Keywords: penal populism, sexual crimes, prostitution, incest, child sexual abuse, secondary victimization.
\end{abstract}

